\title{
MODEL OF FORMING PROFESSIONAL-COMMUNICATIVE COMPETENCE OF STUDENTS OF TECHNICAL UNIVERSITIES IN RUSSIAN LESSONS
}

\author{
Atadzhanova Barno Tulkinovna \\ Senior Teacher of the Department of Primary Education, \\ Ferghana Polytechnic Institute
}

Article DOI: https://doi.org/10.36713/epra2354

\begin{abstract}
ANNOTATION
The article analyzes the concept of professional and communicative competence of technical specialists, presents the component composition of this competency and proposes a technology for its development in a technical university, providing for interdisciplinary coordination and the active use of new information technologies in the learning process.

KEY WORDS: professional and communicative competence, intercultural competence, intersubject coordination, information learning environment, technology of competency formation Introduction
\end{abstract}

\begin{abstract}
Аннотация: В статье выполнен анализ понятия профессионально- коммуникативной компетенции специалистов технического профиля, представлен компонентный состав данной компетенции и предложена технология ее развития в техническом вузе, предусматривающая межпредметную координацию и активное использование средств новых информационных
\end{abstract} технологий в проиессе обучения.

Ключевые слова: профессионально- коммуникативная компетенция, межкультурная компетениия,межпредетная координация, информационная обучающая среда, технология формирования компетенции .

\section{DISCUSSION}

The law on education of the Republic of Uzbekistan States: "the Restructuring of the education system in Uzbekistan aims at young people to acquire solid knowledge in the name of the country's prosperity. The youth issue has always been at the center of state policy. How well we will carry out this task depends on the achievement of such great goals as the prosperity of our homeland, the construction of civil society, economic, spiritual and cultural development, and the country's rise to the level of developed countries." [2,5 ]

The state policy of the Republic of Uzbekistan focuses on the progress of society, training of highly qualified personnel and modern specialists.

The main priority of higher education is comprehensive, harmonious development of the individual. In this regard, pedagogical technology is considered as a description (project) of the entire process of forming the student's personality, and not only as its didactic component.

At present, elements of a new educational system that is fundamentally different in its structure and content are actually being implemented and the transition is being made from a reproductive model of education that works for the reproduction and stability of existing social relations to a productive, humanistic, cultural-oriented system. University teachers have long recognized the need to use new methods and technologies in the process of studying the discipline "Russian language" and all disciplines of the curriculum.

Today, the main goal of learning will prevail communication based on the communicative function of the language. In recent years, a huge amount of research and methodological work has been carried 
out in the field of methods of Russian as a foreign language within the framework of this problem.

Due to the fact that acts of communication with native and other cultures have a different nature, and the problem cannot be reduced to linguistic difference (a detailed analysis of this phenomenon is contained in G. V. Yelizarova, V. V. Safonova) of the Russian Federation, the need for a separate study of professional communicative competence as an important component of communicative competence is not in doubt. However, the presence of different definitions makes us once again touch on this problem.

In recent years, another term is often found in publications - "intercultural communicative competence" (O. R. Bondarenko, K. V. Golubina, K. M. Irishanova, I. L. Pluzhnik) of the Russian Federation. The authors consider this competence in relation to students of language specialties, for whom it is a professional, rather than a key (General cultural) one. Students of technical universities with a very limited number of subjects in the Humanities cycle, including the discipline "Russian language", will not be able to develop a full-fledged intercultural communicative competence, in addition, in the business communication of engineers, some components of this competence will be redundant. Nevertheless, we recognize the need to strengthen the cross-cultural component in the development of professional and communicative competence of students of technical universities.

First, we will briefly focus on the factors that determine the features of the development of professional and communicative competence of technical University students. In our opinion, this topic is poorly covered in the literature, but there are a number of works that contain an analysis of this problem. Summarizing the material of publications, as well as the author's personal experience, we note the main points.

First, the technical University, as well as other non-linguistic universities, is characterized by a significant differentiation of the initial level of development

professional and communicative competence of firstyear students [1]. In a language University, this problem is not so acute, because applicants either pass an exam in a foreign language, which guarantees a certain level of PAC, sufficient for further successful training. In a non-linguistic University, the initial level of professional and communicative competence development is not checked upon admission, so first-year students usually pass the entrance test at the first lesson in a foreign language. When applying the international classification of foreign language proficiency levels, levels from A1 (survival level) to B2 (threshold, advanced) can be recorded within a single student group.
Secondly, based on the results of questionnaires and surveys, we can conclude that there is a significant differentiation in the level of motivation for the development of professional and communicative competence, and it often depends on the level of foreign language proficiency, as a result of which

students with the lowest starting level, not believing in their strength, in the process of learning even more distant from their "advanced" classmates, increasing the level of differentiation.

Russian Russian is a very limited number of classroom hours at a technical University. The Russian language is taught in the 1st year of study. Fourth, the cognitive style of technical University students has its own characteristics. Research shows that students of technical they have good logical thinking, developed in the study of exact Sciences, are able to Express thoughts accurately and concisely, they are familiar with new information technologies and are happy to use them, but on average, they have less developed emotional more than humanist students, their communication skills in their native language often need additional development [6].

The factors listed above determine the high complexity, multi-factoricity and variability of the process of developing professional and communicative competence of technical University students. In search of effective ways to manage this process, special attention should be paid to modern information technologies. A large number of publications have been devoted to the study of this problem, but currently there are no proven technologies for the development of professional and communicative competence, taking into account the specifics of specific specialties, which actively use the capabilities of e-learning tools. As a result, the introduction of information technologies in the learning process is often haphazard, which does not allow to achieve a tangible effect.

In our opinion, information technology tools should serve as an effective solution of didactic tasks in the learning process, and therefore become an integral part of the educational process pedagogical technology for the development of professional and communicative competence. This approach involves the creation of a single information educational environment . In publications on the problems of formation and use of the information learning environment, it is noted that it allows students to rationally organize their work, integrate various methods and forms of learning [3].

We believe that the current level of development of information technologies allows us to create a learning environment that takes into account all features of the development of professional and communicative competence in a technical University, based on the principles of professional orientation, interdisciplinarity, individualization and 
differentiation of training, activation of independent work of students.

In such an information and training environment, tools for developing professional and communicative competence should be integrated with e-learning resources in various disciplines, which provides opportunities for establishing natural interdisciplinary connections. Maintaining a database of regulatory requirements for learning outcomes, the current state of development of professional and communicative competence and the dynamics of personal development of each student will allow you to form and adjust individual learning paths in a timely manner.

All the conditions for the formation of an integrated information learning environment are already available in almost all technical universities a developed information network connected to the Internet, the availability of educational software, qualified personnel. Much more complex are the didactic problems of using information technology tools in the formation process.

Given the high complexity of the process of forming a PAC using an information learning environment, it is advisable to use pedagogical modeling as the basis for the development of training technology. According to P. I. Obraztsova, the main components of the model of informational educational environment in the University are a model of discipline ("what to teach"), the student model ("whom to teach") and the model of the learning process ("how to teach") [4]. In many publications (A. G. Atanov, M. G. Kolyada) the model of the academic discipline is called the model of the subject area of training, which can be interdisciplinary.

Let's take a closer look at each of the components. In search of an answer to the question "what to teach?" it is necessary to determine the component composition of the PAC of a technical University graduate. We took as a basis the description of communicative competence offered By V. V. Safonova [5]. In our opinion, it is complete, logical, and the designations correspond to the terminology.

However, the specifics of professional communication of engineers require a certain revision of the component composition of the PAC, taking into account that the success of communication does not require perfect knowledge of all the nuances of a foreign language, but a significant role is played by professional competence, knowledge of foreign language professional vocabulary, the ability to build speech strategies, etc.in this regard, we will allocate an additional linguistic and professional component in the structure of the PAC, agreeing with the term used by A. S. Andrienko [1]. As a result, we get the structure of the PAC of a technical University graduate, shown in figure 1.

THE INTER DISCIPLINARY NATURE OF THE PPC.

Rice.1

DISCIPLINES OF COMPETENCE

\begin{tabular}{|l|l|l|}
\hline $\begin{array}{l}\text { HUMANITARIAN } \\
\text { CYCLE }\end{array}$ & SOCIO-CULTURAL \\
\hline RUSSIAN & & LINGUISTIC \\
\hline $\begin{array}{l}\text { PROFESSIONAL } \\
\text { CYCLE }\end{array}$ & & SPEECH \\
\hline
\end{tabular}

The diagram shown in figure 1 allows defining the areas of responsibility of various disciplines for the development of the components of the PAC and highlighting the special role of the discipline "Russian language in the professional sphere" (Fig. 2).
Professional communicative (foreign language ) competenc e of a technica 1 University graduate 
Rice. 1. Component composition of the PAC of a technical University graduate

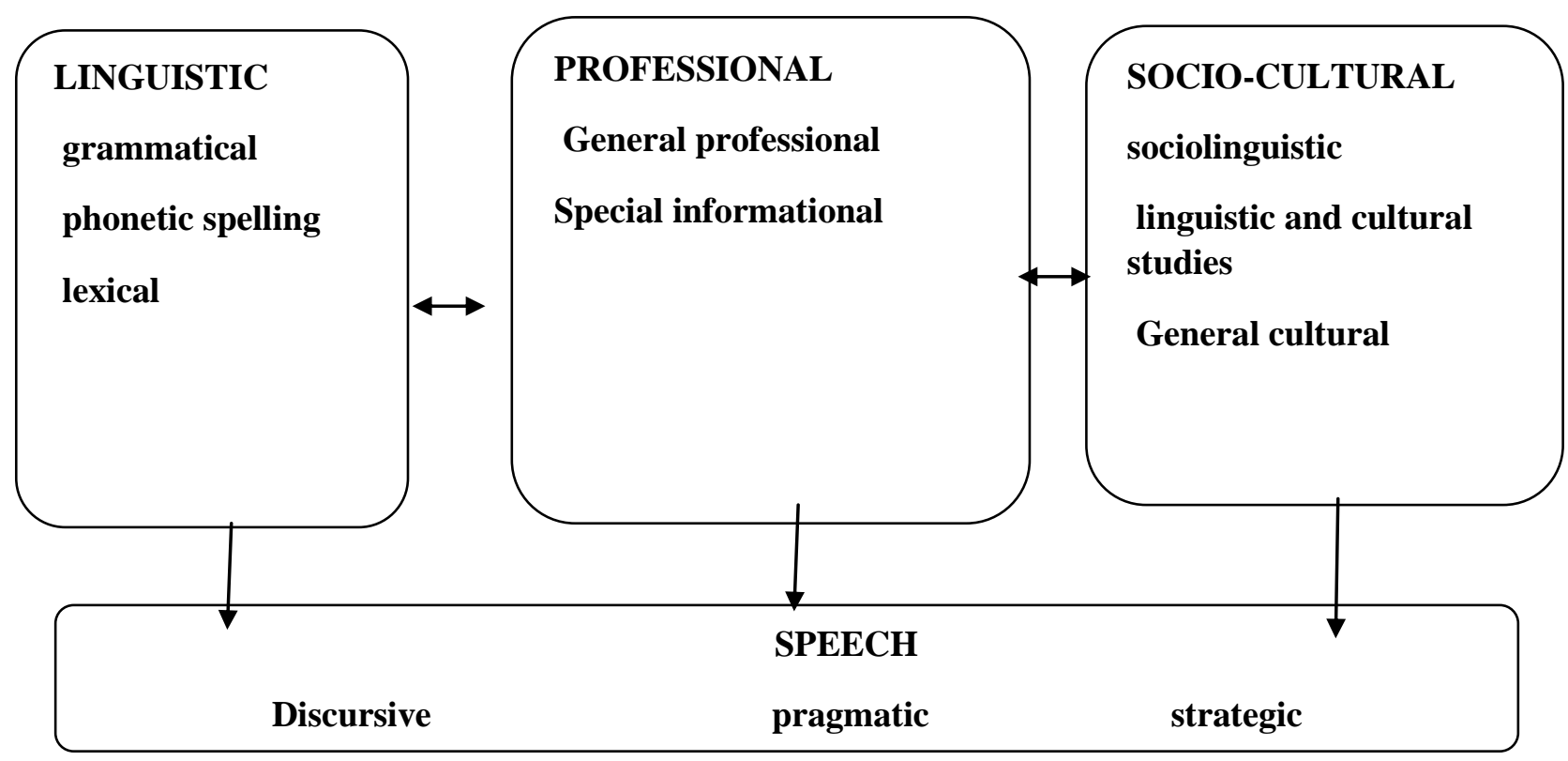

It can be concluded that in the process of developing the PAC in an integrated information learning environment, the Russian language acts as a link between the disciplines of the Humanities and professional cycles. The integrated nature of the environment makes it possible to implement the principle of interdisciplinarity. Implementation of the principles of individualization and differentiation of training, activation of independent work requires close attention to the personality of the student in the framework of a personal development approach, which necessitates the analysis of the personal model of a student of a technical University. In our opinion, the use of information technology tools allows accumulate and then analyze the individual characteristics of the student using a model that includes the following components:

- Motivational-value (motivation for the development of PAC, tolerance, accuracy).

All the personal characteristics that are part of this model can be measured quantitatively or qualitatively, the dynamics their development can be diagnosed and then used to adjust individual learning paths in a timely manner.

Based on the above, in order to solve problems in teaching, we will form a model for the formation and development of the PAC in the Russian language lessons of technical University students, which is the main subject this article (Fig. 3). 


\section{Rice. 3. MODEL OF FORMING BCC OF TECHNICAL UNIVERSITY STUDENTS IN RUSSIAN LANGUAGE LESSONS BASED ON THE INFORMATION LEARNING ENVIRONMENT.}

\section{TARGET BLOCK}

Tasks: - teaching reading, writing, speaking, listening taking into account the professional context-fostering tolerance, attitudes to mutual understanding with foreign partners development of cognitive, emotional-volitional, and activity spheres

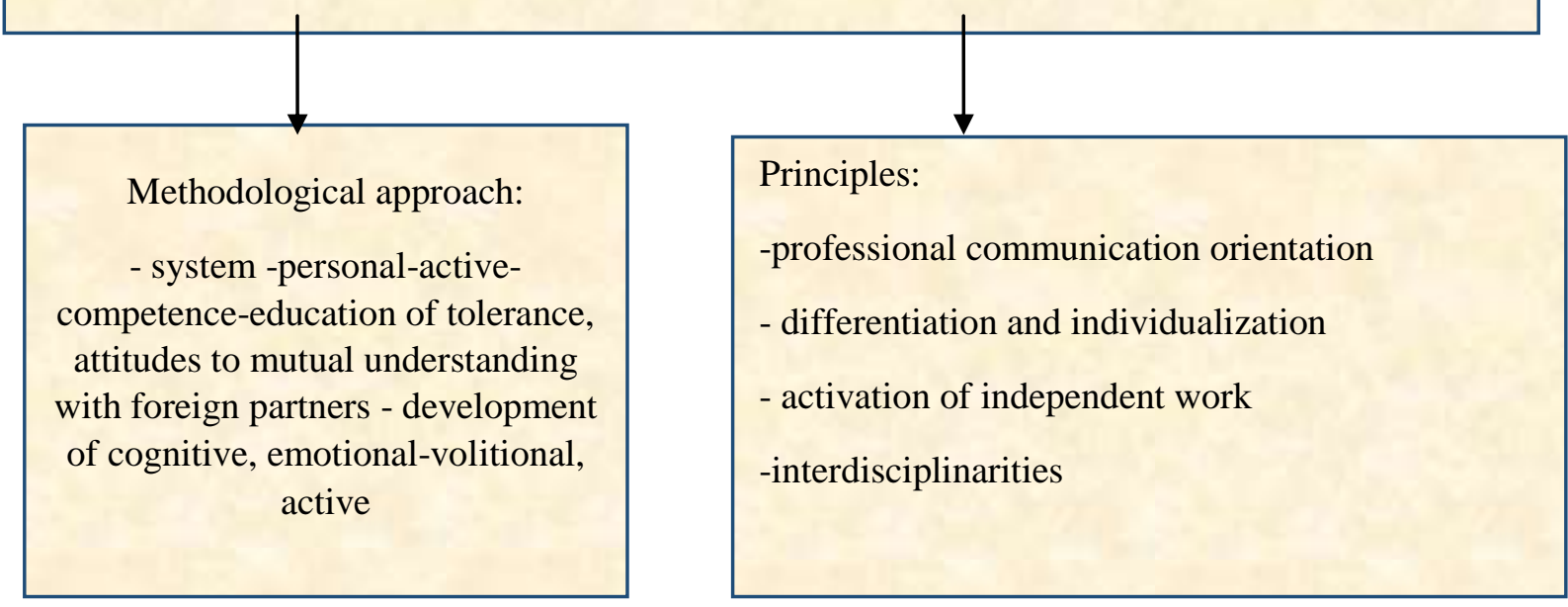

\section{CONTENT BLOCK}

Educational materials on vocabulary, grammar, and country studies

System of educational tasks - situations of professional and technical communication

Authentic text system (articles, technical documentation on hardware and software operation, Wikipedia materials in Russian

\section{ORGANIZATIONAL BLOCK}

The formation of the information educational environment, integrated with training resources in professional disciplines 


\section{PROCESS BLOCK}

\section{Classroom classes \\ - explanatory and illustrative \\ - problem statement \\ - heuristic \\ - problem lecture-seminar \\ -discussions on scientific \\ and technical issues \\ problems \\ - role-playing games- \\ situations \\ professional communication \\ - reports, project protection}

the means of visual

presentation

training material

(presentations,

slides, video and audio

materials
Independent work

- reproductive

- research

FORMS

TOOLS

conditions in Russian

Internet

\section{CONTROL AND ADJUSTMENT BLOCK}

- preparation of technical projects

for the Russian language

training programs, electronic

UMK, software products with

English language

interface, Internet resources, electronic

- working with training programs

- working with professional

software products with a

-solving problems in professional

disciplines with terms and

- search for information in the

Russian- speaking sector The

BLOCK

Diagnostics of the starting level, formation of individual trajectories

Constant monitoring and adjustment of individual trajectories

Forms: tests, surveys, observation, questionnaire, conversation. 


\section{Result: the level of development of all PC components sufficient for successful} intercultural professional - oriented communication

The model presented by us is being studied at the Ferghana Polytechnic Institute when teaching students of the power engineering faculty in the areas of "automation and control" and "power Engineering". The information learning environment includes the following elements: a textbook on Russian grammar with professional vocabulary and tests, video tutorials; RUDN training programs, resources of the RUDN electronic library, etc.

As the results of the experiment show, the use of this model has a positive effect on the development of all components of professional and communicative competence and personal characteristics of students, contributes to increasing motivation to learn.

\section{BIBLIOGRAPHIC LIST}

1. From The Message Of The President of The Republic Of Uzbekistan Shavkat Mirziyoyev To The Oliy Majlis 24.01.2020

2. Law of the Republic of Uzbekistan on education. Tashkent: Uzbekistan, 1997.

3. Resolution of the President of the Republic of Uzbekistan no. PP -3151 "on measures to further expand the participation of industries and sectors of the economy in improving the quality of specialists with higher education".

4. Pedagogical conditions and principles of formation of professional-communicative competence in a future specialist-bachelor in the process of professional training.-Materials of the scientific and practical conference "Innovative development of the Samarkand region: problems and solutions; Samarkand 2020

5. Atajanova B. T. The scientific text as a source of enrichment of the professional language; Herald pedagogiki. «Nauka $i$ Praktyka wydanie specjalne»page 70

6. Andrienko A. S. Development of foreign language professional communicative competence of students of technical higher education (based on credit-modular technology of training: author's abstract. dis. Cand. PED. science / southern Federal University university. - Rostov-on-don, 2007.

7. Elizarova G. V. Formation of intercultural competence of students in the process of teaching foreign language communication: Dis.d RA PED. sciences' /Russian state pedagogical University University. A. I. Herzen. - SPb., 2003. -

8. Zaitseva E. N. Information and learning environment as a means of developing students ' independent work in teaching a foreign language: Dis. ... Cand. PED. Sciences / peoples ' friendship University of Russia. - Moscow, 2003. - 204 c.

9. Obraztsov P. I. Psychological and pedagogical aspects of the development and application of information technologies in higher education. Orel: OrelGTU, 2000.

10. Safonova $V . \quad$. communicative competence: modern approaches towards multi-level description in a methodical order. - Moscow: publishing house of SIC"Euroschool", 2004.

11. Resolution of the President of the Republic of Uzbekistan no. PP -3151 "on measures to further expand the participation of industries and sectors of the economy in improving the quality of specialists with higher education". 